Canadian

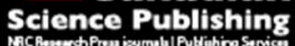

Canadian Journal of Microbiology Revue canadienne de de microbiologie

\title{
Seasonal Changes in Bacterial Communities Associated with Healthy and Diseased Porites Coral in Southern Taiwan
}

\begin{tabular}{|r|l|}
\hline Journal: & Canadian Journal of Microbiology \\
\hline Manuscript ID & cjm-2016-0100.R1 \\
\hline Manuscript Type: & Article \\
\hline Complete List of Authors: & $\begin{array}{l}\text { Lin, Chorng-Horng; DaYeh University, Bioresources } \\
\text { Chuang, Chih-Hsiang; National Dong Hwa University, Graduate Institute of } \\
\text { Marine Biology } \\
\text { Twan, Wen-Hung; National Taitung University, Department of Life Sciences } \\
\text { Chiou, Shu-Fen; National Sun Yat-sen University, Department of Marine } \\
\text { Biotechnology and Resources } \\
\text { Wong, Tit-Yee; University of Memphis, Department of Biology } \\
\text { Liu, Jong-Kang; National Sun Yat-sen University, Department of Biological } \\
\text { Sciences } \\
\text { Kuo, Jimmy; National Museum of Marine Biology and Aquarium, } \\
\text { Department of Planning and Research; National Dong Hwa } \\
\text { University, Graduate Institute of Marine Biology }\end{array}$ \\
\hline Keyword: & \begin{tabular}{l} 
Coral disease, Primer effects, Pink spot syndrome, DGGE \\
\hline
\end{tabular} \\
\hline
\end{tabular}

\section{SCHOLARONE \\ Manuscripts}


1 Seasonal Changes in Bacterial Communities Associated with Healthy and Diseased Porites Coral in Southern Taiwan

4 Chorng-Horng Lin ${ }^{1}$, Chih-Hsiang Chuang ${ }^{2}$, Wen-Hung Twan ${ }^{3,4}$, Shu-Fen Chiou ${ }^{5}$,

5 Tit-Yee Wong ${ }^{6}$, Jong-Kang Liu ${ }^{7}$, Chyuan-yao Kao ${ }^{2}$, and Jimmy Kuo ${ }^{2,3^{*}}$

6

$7{ }^{1}$ Department of Bioresources, DaYeh University, Chang-Hua 51591, Taiwan;

$8 \quad$ clin@mail.dyu.edu.tw

$9{ }^{2}$ Graduate Institute of Marine Biology, National Dong Hwa University, Pingtung

1094450, Taiwan; job.kuosam0215@gmail.com; megapufferfish@gmail.com

$11{ }^{3}$ Department of Planning and Research, National Museum of Marine Biology and 12 Aquarium, Pingtung 94450, Taiwan; jimmy@nmmba.gov.tw

$13{ }^{4}$ Department of Life Sciences, National Taitung University, Taitung 95002,

14 Taiwan; twan@nttu.edu.tw

$15{ }^{5}$ Department of Marine Biotechnology and Resources, National Sun Yat-sen

16 University, Kaohsiung 80424, Taiwan; sfc@mail.nsysu.edu.tw

$17{ }^{6}$ Department of Biology, University of Memphis, Memphis, TN 38152, USA;

18 tywong@memphis.edu

$19{ }^{7}$ Department of Biological Sciences, National Sun Yat-sen University, Kaohsiung 20 80424, Taiwan; jkliu@faculty.nsysu.edu.tw

${ }^{*}$ Corresponding author. Mailing address: National Museum of Marine Biology and Aquarium, Pingtung 944, Taiwan. Phone: 886-8-8825045. Fax: 886-8-8825087. E-mail: jimmy@nmmba.gov.tw. 


\section{Abstract}

23 We compared the bacterial communities associated with healthy scleractinian

24 coral Porites sp. with those associated with coral infected with pink spot

25 syndrome harvested during summer and winter from waters off the coast of

26 southern Taiwan. Members of the bacterial community associated with the coral

27 were characterized by means of denaturing gradient gel electrophoresis (DGGE)

28 of a short region of the $16 \mathrm{~S}$ rRNA gene and clone library analysis. Of five

29 different areas of the 16S rRNA gene, we demonstrated that the V3 hypervariable

30 region is most suited to represent the coral-associated bacterial community. The

31 DNA sequences of 26 distinct bands extracted from DGGE gels and 269

32 sequences of the $16 \mathrm{~S}$ rRNA gene from clone libraries were determined. We found

33 that the communities present in diseased coral were more heterogeneous than the

34 bacterial communities of uninfected coral. In addition, bacterial communities

35 associated with coral harvested in the summer were more diverse than those

36 associated with coral collected in winter, regardless of the health status of the

37 coral. Our study suggested that the compositions of coral-associated bacteria

38 communities are complex, and the population of bacteria varies greatly between

39 seasons and in coral of differing health status. 
40 Keywords: Coral disease; Primer effects; Pink spot syndrome; DGGE.

41 


\section{Introduction}

43 Coral reef is one of the most complex marine ecosystems. Many fish, snails,

44 and lobsters depend on corals for their survival. The global decline in coral

45 populations has endangered this very important ecosystem (Loya et al. 2001; Jones

46 et al. 2004a). Bacteria are ubiquitous in every habitat on earth. The symbiotic

47 relationships between bacteria and corals have been investigated using various

48 techniques (Kellogg 2004; Wegley et al. 2007; Chiou et al. 2010; Kimes et al.

49 2013; Lema et al. 2014). It is now known that corals harbor many different types of

50 bacteria (Frias-Lopez et al. 2002; Rohwer et al. 2002; Chiou et al. 2010; Ceh et al.

51 2011; Lema et al. 2014), archaea (Ferris et al. 1996; Kellogg 2004), and fungi

52 (Bentis et al. 2000; Wegley et al. 2007) and their associations are often host

53 species-specific (Rohwer et al. 2001; Rohwer et al. 2002). However, bacteria-coral

54 associations are not always stable: evidence suggests that environmental change

55 could disrupt the microbe-coral association, leading to either a new adaptation or to

56 coral disease (Rosenberg et al. 2007).

57 During the past 30 years, more than twenty disease signs have been described

58 in corals; however, the causative agents of most coral diseases are still unknown

59 (Rosenberg et al. 2007). Advances in molecular techniques, such as the 16S rRNA 
60 clone library and terminal restriction fragment length polymorphism (T-RFLP),

61 provide culture-independent methods for comparing the differences in microbial

62 communities between healthy and diseased corals (Ritchie and Smith 1995;

63 Frias-Lopez et al. 2002; Cooney et al. 2002; Frias-Lopez et al. 2004; Chiou et al.

64 2010). For example, bacteria isolated from healthy elkhorn coral Acropora palmata

65 and bacteria from the same coral with type 1 white band disease are significantly

66 different (Pantos and Bythell 2006). Similar surveys have shown that there are

67 numerous toxin-producing heterotrophic bacteria in the mucopolysaccharide layer

68 and bacterial mat near the black band area of Siderastrea coral infected with black

69 band disease (BBD) (Sekar et al. 2006). Recently, high-throughput sequencing

70 and microarray technologies have been applied to study microbial communities

71 associated with coral disease, and our knowledge of the abundance, diversity and

72 gene content of microbiota in healthy and diseased coral has increased (Cardenas

73 et al. 2012; Roder et al. 2014; Closek et al. 2014; Ng et al. 2015). These studies

74 not only confirm the changes in bacterial communities of coral affected by disease,

75 but also suggest that dynamic interaction between environmental factors, host

76 immunity, and microbiome plays an important role in coral health, and any 
77 change in these components may have the potential to result in the development

78 of diseases (Cardenas et al. 2012; Roder et al. 2014).

79 There are several methods currently available for identifying bacteria without

80 prior knowledge of the bacterial community. PCR-DGGE (polymerase chain

81 reaction-denaturing gradient gel electrophoresis) for DNA amplification and

82 separation techniques coupled with DNA sequencing is one of these methods and

83 has been used successfully to characterize and compare the microbial diversity and

84 community structure in environmental samples (Muyzer et al. 1993). This

85 culture-independent method compares microbial communities by examining how

86 far 16S rDNA fragments of different bacteria move through a polyacrylamide gel.

87 The gel bands are then excised, sequenced and compared with reference 16S rRNA

88 genes in the database. Although this technique is now routinely carried out for the

89 analysis of microbial diversity, selection of the region(s) of the 16S rRNA gene that

90 could provide the most information about the bacterial community is primarily

91 based on experience; selection of the 16S rRNA gene regions, and thus the choice

92 of primer set, can greatly affect the outcome (Yu and Morrison 2004). Even so, few

93 studies have critically analyzed the choice of primers for study of the bacterial

94 communities associated with corals (Yu and Morrison 2004; Sanchez et al. 2007; 
95 Yu et al. 2008). Moreover, only a small number of researchers have analyzed how

96 seasonal changes affect the coral bacteria association (Bourne et al. 2008; Hong et

97 al. 2009; Ceh et al. 2011; Kimes et al. 2013; Lema et al. 2014).

98 Invasion of trematodes in Porites tissue causes bright pink spots to appear on

99 the surface of the coral. This disease is called pink spot syndrome (PSS) (Aeby

100 2003). Recently, Benzoni et al. (2010) reported that trematodiasis is only a

101 secondary infection of the already weakened Porites. The bacterial community

102 associated with PSS in coral has never been studied. In the present study, we

103 therefore used PCR-DGGE and DNA sequencing techniques to characterize and

104 compare the dominant members of the bacterial community associated with healthy

105 and PSS Porites. Porites sp. was harvested from Nanwan at Kenting National Park

106 in southern Taiwan. We used five different primer sets to amplify different

107 hypervariable regions of the $16 \mathrm{~S}$ rRNA and compared the quality of information

108 obtained. We also examined the dynamics of the bacterial communities in coral

109 collected in summer and in winter. 


\section{Materials and methods}

\section{Sampling}

113 Fragments of separate colonies of Porites sp. coral were collected at a depth

114 of approximately 7 meters near Nanwan $\left(21^{\circ} 57^{\prime} 1.78^{\prime \prime} \mathrm{N}, 120^{\circ} 46^{\prime} 13.8^{\prime \prime} \mathrm{E}\right)$ at

115 Kenting National Park in southern Taiwan during summer (June, 2007) and winter

116 (November, 2007). The samples (obtained in triplicate) were divided into four

117 groups: healthy colonies collected in summer ( $\mathrm{SH} \mathrm{1-3),} \mathrm{pink} \mathrm{spot-diseased}$

118 colonies collected in summer (SD 1-3), healthy colonies collected in winter (WH

119 1-3), and the pink spot-diseased colonies collected in winter (WD 1-3). The

120 average seawater temperature in June and November at the times of sampling was

$12129.0 \pm 0.9$ and $24.7 \pm 0.8{ }^{\circ} \mathrm{C}$, respectively (Hsieh 2009). Coral samples were

122 collected underwater using a hammer and chisel. Each sample was placed in an

123 individual sterile plastic bag with seawater. Samples were delivered to the

124 laboratory in an ice box within 30-60 min, whereupon the seawater within each

125 plastic bag was decanted and the sample stored at $-20{ }^{\circ} \mathrm{C}$ until analysis.

126

127 DNA extraction 
$130 \mathrm{CaCl}_{2} 2 \mathrm{H}_{2} \mathrm{O}, 0.671 \mathrm{~g} / \mathrm{L} \mathrm{KCl}, 0.168 \mathrm{~g} / \mathrm{L} \mathrm{NaHCO}_{3}$, and $2.384 \mathrm{~g} / \mathrm{L}$ HEPES) and

131 pulverized using a mortar and pestle. The sample was transferred to a $50-\mathrm{mL}$

132 centrifuge tube, mixed with $10 \mathrm{~mL}$ TE buffer (10 mM Tris-HCl, $\mathrm{pH}$ 8.0, $1 \mathrm{mM}$

133 EDTA), and shaken at $4{ }^{\circ} \mathrm{C}$ for $10 \mathrm{~h}$. Bacterial genomic DNA from the 134 supernatant was extracted using a PowerMax Soil DNA Isolation kit (MO BIO 135 Laboratory, Carlsbad, CA, USA).

\section{PCR amplification of $16 S$ rRNA fragments}

The 16S rRNA gene sequences from 8 to 1513 bp of Escherichia coli were

amplified by PCR using a method modified from that used by Muyzer et al.

143 volume of $50 \mu \mathrm{L}$ and contained $1 \mu \mathrm{L}$ (roughly $10 \mathrm{ng}$ ) of coral bacterial genomic

144 DNA, 500 pmoles of each primer, $100 \mu$ moles of dNTP, $5 \mu \mathrm{L}$ of 10X PCR buffer

$145\left(100 \mathrm{mM}\right.$ Tris- $\mathrm{HCl}, \mathrm{pH} 8.3,15 \mathrm{mM} \mathrm{MgCl}_{2}$, and $\left.500 \mathrm{mM} \mathrm{KCl}\right)$, and $2.5 \mathrm{U}$ of Taq 
146 DNA polymerase (Takara Bio, Otsu, Japan). Touchdown PCR was performed

147 using a GeneAmp PCR System 2400 (Perkin-Elmer Applied Biosystems, Foster

148 City, CA, USA) with the following protocol: 1 cycle of 5 min at $94{ }^{\circ} \mathrm{C} ; 30$ cycles

149 of $30 \mathrm{~s}$ at $94{ }^{\circ} \mathrm{C}, 30 \mathrm{~s}$ at $65-55^{\circ} \mathrm{C}\left(-0.5^{\circ} \mathrm{C} /\right.$ cycle $)$, and $90 \mathrm{~s}$ at $72{ }^{\circ} \mathrm{C}$; 1 cycle of 10

$150 \min$ at $72{ }^{\circ} \mathrm{C}$. The PCR products were resolved on $2 \%$ agarose gels; bands were

151 purified using a QIAquick Gel Extraction kit (Qiagen, Santa Clarita, CA, USA)

152 and sub-cloned into yT\&A vector (Yeastern, Taipei, Taiwan) for clone library

153 construction.

154 Nested PCR was used to amplify five different V regions of the bacterial $16 \mathrm{~S}$

155 rRNA following the method of Sanchez et al. (2007), with the above mentioned

156 amplified 16S rRNA gene as the template. The PCR primer sets and annealing

157 conditions used to amplify the specific 16S rRNA sequences for DGGE analysis

158 were as shown in Table 1.

160 DGGE separation of 16S rRNA fragments

161 DGGE was performed essentially as described previously (Muyzer and de

162 Waal 1994; Muyzer et al. 1996; Sanchez et al. 2007) using a Bio-Rad D-Code

163 System (Bio-Rad, Hercules, CA, USA). PCR fragments were separated on 6 or 
$1648 \%(\mathrm{v} / \mathrm{v})$ polyacrylamide $(37.5: 1$ ratio of acrylamide to bisacrylamide) gels. A

165 gradient of 45 to $65 \%$ denaturant was used to separate the PCR products; $100 \%$

166 denaturant contained $7 \mathrm{M}$ urea and 40\% formamide. Electrophoresis was carried

167 out at $100 \mathrm{~V}$ for $14 \mathrm{~h}$ in $1.0 \times \mathrm{TAE}$ buffer at a constant temperature of $60^{\circ} \mathrm{C}$. The

168 detailed DGGE conditions used for different primer sets are listed in Table 1. Gels

169 were stained with SYBR Green I (Molecular Probes, Eugene, OR, USA) prepared

170 in $1.0 \times$ TAE buffer $(1: 10000, \mathrm{v} / \mathrm{v})$ for $30 \mathrm{~min}$ and finally photographed using a

171 Typhoon Trio scanner (GE Healthcare, Piscataway, NJ, USA).

172

173 Clone library construction and analysis

174 Clone libraries were constructed from the amplified 16S rRNA from each

175 sample. Bacterial clones from each library were selected randomly and

176 PCR-amplified with the M13 forward and reverse primers supplied with the

177 cloning kit. The PCR products of the bacterial clones were digested with

178 restriction enzymes HhaI and NlaIII (Fermentas, Hanover, MD, USA) according

179 to the manufacturer's directions. The resulting restriction fragment length

180 polymorphism (RFLP) patterns were analyzed on a $2 \%$ agarose gel stained with 
181 ethidium bromide. Clones were grouped according to RFLP pattern and

182 representative clones were sequenced.

183

184 Isolation, PCR, cloning and sequencing of DGGE bands

185 The DGGE bands were excised from the gel and transferred to a

186 microcentrifuge tube. To elute the DNA from the gel fragment, $30 \mu \mathrm{L}$ of distilled

187 water were added to the gel fragment and the mixture was ground with a plastic

188 pestle and heated for $10 \mathrm{~min}$ at $80^{\circ} \mathrm{C}$. Approximately $1 \mu \mathrm{L}$ of the mixture was

189 used for PCR amplification. PCR amplification was carried out using a GeneAmp

190 PCR System 2400 with the following temperature profile: initial denaturation at

$19194{ }^{\circ} \mathrm{C}$ for $3 \mathrm{~min}$, followed by 35 cycles of denaturation at $94{ }^{\circ} \mathrm{C}$ for $30 \mathrm{~s}$,

192 annealing at $55{ }^{\circ} \mathrm{C}$ for $30 \mathrm{~s}$, and extension at $72{ }^{\circ} \mathrm{C}$ for $1 \mathrm{~min}$, with a final

193 extension at $72{ }^{\circ} \mathrm{C}$ for $10 \mathrm{~min}$. The fragments were cloned using the methods

194 outlined previously. Plasmid purification was performed using a QIAprep Spin

195 Miniprep kit (Qiagen) and DNA sequencing was completed at National Cheng

196 Kung University (Tainan, Taiwan).

197

198 DGGE band pattern analysis 
DGGE bands were identified using the Quantity One 4.5 free-trial program

200 (Bio-Rad) with default settings. The differences in the banding pattern between

201 two gel tracks were converted into binary data, and the distance matrix was

202 calculated according to the Dice similarity coefficient. The Dice similarity

203 coefficient $\left(S_{D}\right)$ between gel track $\mathrm{A}$ and B is defined as $S_{D}=2 N_{A B} /\left(N_{A}+N_{B}\right)$,

204 where $N_{A}$ is the total number of bands in $\mathrm{A}, N_{B}$ is the total number of bands in B,

205 and $N_{A B}$ is the number of bands common to A and B (Eichner et al. 1999). The

206 unweighted pair group method with arithmetic mean (UPGMA) was used to

207 create dendrograms. The diversity of the coral-associated bacterial community

208 was assessed using the Shannon-Wiener diversity index $(H)$, which is defined as

$209 H=-\sum\left(P_{i} \ln P_{i}\right)$, where $P_{i}$ is the importance probability of the bands in a track and

210 In represents the natural logarithm function. The importance probability is defined

211 as $P_{i}=n_{i} / N$, where $n_{i}$ is the height of a peak and $N$ is the sum of all peak heights in

212 the curve (Eichner et al. 1999).

214 Sequence analysis

215 16S rRNA gene fragments were compared with those in the SILVA SSU Ref

216 databases release 119 (Pruesse et al. 2007) using the basic local alignment search 
217 tool (BLAST) (Altschul et al. 1990) algorithm to identify known sequences with a

218 high degree of similarity. In addition, we also used the Ribosomal Data Project

219 (RDP) classifier tool (Wang et al. 2007) to classify 16S rRNA gene fragments by

220 bacterial taxonomy. A $70 \%$ confidence threshold was used to assign sequences to

221 a taxonomical hierarchy; however, a 50\% confidence threshold was applied for

222 assigning sequences at the phylum level (Liu et al. 2008).

223 To build the phylogenetic tree, all of the sequences were imported into the

224 ARB program (Ludwig et al. 2004). 16S rRNA sequences obtained from the clone

225 libraries were aligned with a data set containing the nearest relative matches using

226 the positional tree server from the ARB program. A neighbor-joining tree was

227 constructed with Jukes-Cantor correction using sequences obtained from the clone

228 libraries. The statistical significance of tree branches was evaluated by bootstrap

229 analysis involving the construction of 1000 trees from randomly resampled data.

230 Short DGGE band sequences were added to the tree using the ARB parsimony

231 insertion tool.

232 The nucleotide sequences obtained in the present work are available in the

233 GenBank database (KM078980 to KM079077). 


\section{Results}

\section{DGGE profiles using different primer sets}

237 Five different hypervariable regions of the 16S rRNA sequence from extracts 238 of (A) healthy coral collected in summer (labeled SH 1 to 3), (B) diseased colonies 239 collected in summer (labeled SD 1 to 3), (C) healthy colonies collected in winter

240 (labeled WH 1 to 3), and (D) diseased colonies collected in winter (labeled WD 1 to

2413 ) were amplified using five different primer sets. The amplified DNA fragments of

242 each sample were resolved by DGGE (Fig. 1). Comparing individual samples (A

243 through D), the overall banding patterns of triplicate samples of each group were

244 generally similar. Occasionally, a band was absent in one of the triplicates (as

245 indicated by thin lines) but present in the other two replicates. These slight

246 differences are likely due to local variations of bacteria in different colonies.

247 When the five gel patterns were compared, it was clear that the banding profile

248 is directly influenced by the primer set used for PCR. It is also clear that regardless

249 of the primer set used, the bacterial community that the corals harbored differed

250 between seasons. The health status of the coral was also observed to be a major 251 factor affecting the bacterial constituents. 
252 As the band patterns of the samples are subject to the specificity of the primer

253 set, it was necessary to evaluate which primer set could provide the most

254 information. We used the Dice similarity coefficient for pairwise comparison of the

255 band profiles for each DGGE gel, then employed the UPGMA clustering method to

256 virtualize their relationships. We found that primer set GC357F-518R (V3 region,

257 Fig. 2C) provided the best cluster in terms of both season and health status,

258 although sample WD1 appeared to be closely related to the SH1, SH2 and SH3

259 cluster. Primer sets GC63F-518R (V1-V3 region, Fig. 2A) and GC968F-1401R

260 (V6-V8 region, Fig. 2D) clustered the samples according to health status, with the

261 exceptions of WD1 and SD2. Primer set GC357F-907R (V3-V5 region, Fig. 2B)

262 clustered the samples according to season, with the exceptions of SD2 and WD1.

263 To further evaluate these primer sets, we considered the number of bands and

264 the corresponding Shannon diversity index for each group of coral samples (Fig. 3).

265 The primer set GC357F-518R had both the highest average number of bands (35.9,

266 Fig. 3A) and the highest average Shannon diversity index (3.38, Fig. 3B). The

267 second highest average number of bands and average Shannon diversity index were

268 obtained with GC968F-1401R, being 30.6 and 3.33, respectively. 

groups of samples showed that the number of bands generated using primer set

271 GC357F-518R was significantly influenced by the season in which the sample was

272 collected $(\mathrm{P}<0.001)$, the health status of the coral $(\mathrm{P}<0.001)$, and the interaction

273 between season and health $(\mathrm{P}<0.001)$. Primer sets GC968F-1401R and

274 GC1055F-1392R also produced significantly different results between seasons

275 (both $\mathrm{P}<0.05)$ and in corals of differing health status $(\mathrm{P}<0.05$ and $\mathrm{P}<0.001$,

276 respectively); however, the differences were less significant than those obtained

277 using primer set GC357F-518R. Primer set GC357F-907R resulted in a significant

278 difference only between corals of differing health status $(\mathrm{P}<0.05)$. Primer set

279 GC63F-518R resulted in no differences being observed between corals collected in

280 different seasons and those with differing health status. Interestingly, the same

281 results were obtained using two-way ANOVA to compare the Shannon diversity

282 index between different groups of samples for each primer set.

283 Based on the band patterns, number of bands, and Shannon diversity indices

284 obtained by analysis of the DGGE banding profiles, we concluded that

285 GC357F-518R was the best primer set for analyzing the bacterial community of the 
286 coral. Primer set GC968F-1401R was the second best, whereas GC357F-907R was

287 least preferable for analysis of the bacterial community of the coral.

289 DGGE analysis

290 By examining the numbers of bands and the Shannon diversity indices

291 resulting from the use of the GC357F-518R primer set, as shown in Fig. 3, we

292 found that the number of bands in the DGGE gels varied from 26 to 40, which

293 suggests that the bacterial community associated with the coral is complex. It was

294 also observed that the species richness and species diversity associated with the

295 corals decreased in winter, while these factors increased when the corals were

296 affected by disease. The species richness and diversity of the bacterial community

297 were lowest in healthy coral samples collected in winter.

\section{DGGE band sequence analysis}

300 The 16S rRNA gene fragments of the DGGE bands obtained using primer set

301 GC357F-518R (Fig. 1C) were eluted from the gel and amplified by PCR. 
302 Twenty-six fragments were cloned and their sequences determined. The lengths of

303 these sequences ranged from 164 to $198 \mathrm{bp}$, with an average length of $183.5 \mathrm{bp}$. The

304 DNA sequences of these fragments were then compared with those in the SILVA

305 database, and the values for sequence similarity with the closest matched sequences,

306 as well as the phylogenetic affiliations of the 26 distinct clones (B1-B26), are listed

307 in Table $\mathrm{S}^{*}$. A diverse collection of bacteria, including Gammaproteobacteria

308 (34.43\%, 12 clones), Alphaproteobacteria (21.62\%, 8), Deltaproteobacteria

309 (18.92\%, 7), Actinobacteria $(5.41 \%, 2)$, Firmicutes $(5.41 \%, 2)$, Bacteroidetes

$310(2.70 \%, 1)$, Chloroflexi $(2.70 \%, 1)$, Nitrospira $(2.70 \%, 1)$, Verrucomicrobia

$311(2.70 \%, 1)$, and unclassified Proteobacteria $(5.41 \%, 2)$, was matched with the

312 samples.

313

314 Clone library analysis

315 Clone library analysis was performed in each sample group. A total of 269

316 clones from the clone libraries were randomly selected for analysis. The numbers of

317 clones in the $\mathrm{SH}, \mathrm{SD}, \mathrm{WH}$, and WD libraries were 73, 66, 59 and 71, respectively.

\footnotetext{
* Supplementary Material.
} 
318 The RFLP patterns of each clone were compared, and 70 different RFLP ribotypes

319 from the clones were identified. The numbers of distinct ribotypes contained in the

$320 \mathrm{SH}, \mathrm{SD}, \mathrm{WH}$, and WD libraries were 16, 17, 14 and 23, respectively. Clone inserts

321 from the representative ribotypes were partially sequenced and compared with the

322 SILVA database (Table S2 ${ }^{*}$ ). The average length of distinct ribotypes was 775.96

323 bp. The taxonomic group percentages of the 269 bacterial clones from corals of

324 differing status are shown in Fig. 4. The bacterial clones inhabiting the corals were

325 predominantly identified as Alphaproteobacteria (46.10\%, 124 clones),

326 Gammaproteobacteria $(29.38 \%, 79)$, Acidobacteria $(6.69 \%, 18)$, Chloroflexi

$327(4.09 \%, 11)$, Betaproteobacteria $(4.09 \%, 11)$, Deltaproteobacteria $(4.09 \%, 11)$,

328 Firmicutes $(2.23 \%, 6)$, Actinobacteria $(1.86 \%, 5)$, and Gemmatimonadetes $(1.49 \%$,

329 4). In addition, a phylogenetic tree showing the relationships between sequences

330 from four clone libraries and DGGE bands is presented in Fig. 5.

331 As shown in Fig. 4, identification of several tendencies was possible. (1) Most

332 of the bacteria in the summer coral were Alphaproteobacteria, whereas

333 Alphaproteobacteria and Gammaproteobacteria were found in coral collected in

334 winter. (2) Acidobacteria and Firmicutes were only found in diseased coral. (3) The

\footnotetext{
* Supplementary Material.
} 
335 bacteria in healthy coral collected in winter were the least diverse, an observation

336 that independently supported the DGGE analysis results (obtained using

337 GC357F-518R, Fig. 3). (4) Actinobacteria species were only found in coral

338 collected in summer (which was also in good agreement with the DGGE results

339 shown in Table S1).

340 Figure $\mathrm{S}^{*}$ shows the taxonomic classifications of the 269 clones as

341 determined using the RDP classifier tool. Of the 269 clones, approximately half

$342(50.93 \%, 137$ clones) were related to known genera. Members of the family

343 Rhodobacteraceae (including genera Loktanella, Paracoccus, Pseudovibrio,

344 Roseovarius, Silicibacter, and unclassified Rhodobacteraceae) were the most

345 abundant clones in the SH (76.71\%) and SD (57.58\%) samples. Within this family,

346 members of the genus Silicibacter represented $46.43 \%$ and $39.47 \%$ of the clones in

347 the SH and SD samples, respectively. In contrast, members of the

348 Rhodobacteraceae family comprised only $0.00 \%$ and $7.04 \%$ of the clones in the

349 WH and WD samples, respectively.

350 The genera Acinetobacter (27.12\%) and Pseudoxanthomonas (22.03\%) were

351 the most abundant clones in the WH sample. The most abundant clones in the WD

* Supplementary Material. 
352 sample were members of the Gammaproteobacteria (25.35\%) and Rhizobiales

353 families (14.09\%). Most of the clones (77.46\%) in the WD sample could not be

354 classified as belonging to any known family.

355 One ribotype (clone-SD-4) from the SD samples and two ribotypes

356 (clone-WD-7 and clone-WD-9) from the WD samples have previously been

357 identified in BBD-affected Siderastrea siderea colonies (Sekar et al. 2008), and a

358 further ribotype from SD samples (clone-SD-1) and one from WD samples

359 (clone-WD-19) were previously found to be associated with tumors in the coral

360 Platygyra carnosus (Chiu et al. 2012), indicating that unique bacterial

361 communities are involved in disease lesions of different corals. On the other hand,

362 SH samples were found to have one ribotype (clone-SH-9) that was highly similar

$363(100 \%)$ to a sequence previously found in association with diseased Platygyra

364 carnosus (Chiu et al. 2012), suggesting that it is likely to be a ubiquitous

365 coral-associated bacteria. 


\section{Discussion}

368 Pink spot syndrome is a disease caused by infection of Porites coral with

369 trematode Odocotyloides stenometra, which leads to swollen pink nodules on the

370 coral colony (Aeby 2003). A previous study reported that the pink spots are due to

371 the mechanical/chemical stress caused by the settling of barnacle larvae on living

372 Porites (Benzoni et al. 2010). The phenomenon suggests that although the signs of

373 the disease are similar in Porites of different locations, they do not have the same

374 etiology. In addition, parasitic infection might not be the only cause of the disease,

375 and other microorganisms could also play a role in disease formation. Bacterial

376 involvement in other diseases of Porites has been demonstrated; for example,

377 bacterial communities have been found to be correlated with white patch syndrome

378 in Porites (Sere et al. 2013). The roles of these bacterial species in pink spot

379 syndrome therefore need to be examined.

380 In this study, we used DGGE, a frequently-used method for the analysis of

381 bacterial communities in various environments, to characterize the bacterial

382 communities associated with pink spot syndrome and analyze the effects of

383 seasonal factors on the diversity of bacteria. DGGE only profiles the dominant

384 microbes within a community (Muyzer and Smalla 1998). In the present study, we 
385 compared the effects of primer sets on bacterial communities inhabiting coral of

386 different sample groups using PCR-DGGE. Our results suggested that the use of

387 primer set GC357F-518R generated a cluster consistent with season and health

388 status. This primer set produced a wealth of information, and was found to be the

389 best primer set for use to examine the bacterial communities of Porites coral. Yu

390 and Morrison ( $\mathrm{Yu}$ et al. 2008) found that use of the GC357F-518R primer set

391 produced DGGE profiles with the highest species richness and Shannon diversity

392 index in a study of the use of eight different bacterial primer sets to analyze

393 bacterial community DNA extracted from the digesta of sheep. In contrast, Sanchez

394 et al. (Sanchez et al. 2007) reported that primer set 357fGC-907RM grouped

395 samples according to season, and was the most suitable of five different primer sets

396 for PCR-DGGE analysis of marine bacterioplankton communities in an

397 oligotrophic coastal marine system. However, it is interesting to note that they

398 predicted that GC357F-518R could match the most abundant marine

399 bacterioplankton sequences in the RDP database using bioinformatic methods

400 (Sanchez et al. 2007), which could further explain our results. Interestingly, they

401 also predicted that 907RM would not be a good primer for marine bacterioplankton

402 analysis using the same method, which was controversial; however, this result 
403 again agreed with our finding that GC357F-907R was the least useful primer set for

404 PCR-DGGE study of coral bacteria in this study. The reason for the difference in

405 selection of the best primer set in different studies is very possibly due to the

406 differences in microbial flora structure in samples of different studies.

407 The present study analyzed and compared the bacterial community structure

408 and composition inhabiting healthy and diseased coral obtained during two

409 different seasons. Both DGGE and clone library data indicated that the bacterial

410 community structures of the coral were diverse and considerably different between

411 seasons as well as between coral of differing health status. Overall, the bacterial

412 assemblages of coral were composed mainly of Alphaproteobacteria,

413 Gammaproteobacteria, Acidobacteria, Chloroflexi, Betaproteobacteria,

414 Deltaproteobacteria, Firmicutes, Actinobacteria, Gemmatimonadetes,

415 Bacteroidetes, Chloroflexi, Nitrospira, Verrucomicrobia, and unclassified

416 Proteobacteria (Tables S1 and S2). This high level of microbial diversity was in

417 agreement with many previous culture-independent surveys of microbial

418 communities of corals (Rohwer et al. 2001; Rohwer et al. 2002; Bourne et al. 2008).

419 From the number of DGGE bands (357F-518R, Fig. 3A) and the Shannon

420 diversity index (357F-518R, Fig. 3B), we concluded that the bacterial communities 
421 inhibiting healthy coral were significantly more diverse in summer than in winter.

422 This result was further confirmed by comparing the diversity of bacterial

423 communities between two seasons from the clone library data at the phylum/class

424 level (Fig. 4). Our observation was in line with the conclusions of Hong et al. (Hong

425 et al. 2009), who reported that the diversity of bacterial communities associated

426 with the coral Stylophora pistillata is also higher in the summer. In contrast, Porites

427 astreoides-associated bacteria from the Caribbean Sea showed stronger species

428 specificity and little difference between seasons (Wegley et al. 2007). The reason

429 for this difference in temporal influence is not clear, although it has been suggested

430 that temporal influence may be stronger in some regions than others (Littman et al.

$4312009)$.

432 We demonstrated large differences between bacterial communities of the coral

433 in different seasons and in coral of differing health status. More than half of the

434 bacterial clones found in coral collected in summer were members of the

435 Alphaproteobacteria family (Fig. 4). On the other hand, both Gammaproteobacteria

436 and Alphaproteobacteria species were predominant in the samples collected in

437 winter. This shift in bacterial assemblage to Gammaproteobacteria in coral exposed

438 to colder temperatures is parallel with the bacterial communities of the corals 
439 Acropora millepora (Lema et al. 2014) and Stylophora pistillata (Hong et al. 2009).

440 However, other researchers reported a different succession profile of the bacterial

441 community of coral exposed to warmer temperatures (Koren and Rosenberg 2008;

442 Kimes et al. 2013). For example, Gammaproteobacteria (60.9\%) is dominant in

443 summer, and both Alphaproteobacteria (79.5\%) and Gammaproteobacteria

$444(21.5 \%)$ are dominant in winter in the Mediterranean coral Oculina patagonica

445 (Koren and Rosenberg 2008).

446 The health status of the coral has a great impact on the bacterial community, as

447 indicated by the increase in the Shannon diversity index (Fig. 3B, primer set

448 357F-518R) of the bacterial population in diseased coral. Several studies

449 investigating the structure of the bacterial community also observed a distinct

450 difference and a higher diversity in the bacterial communities associated with

451 diseased/bleached corals (Sekar et al. 2006; Pantos and Bythell 2006; Chimetto et

452 al. 2008; Bourne et al. 2008; Sunagawa et al. 2009; Kimes et al. 2013; Closek et al.

453 2014). Coral holobiont is a dynamic equilibrium between the coral animal and its

454 associated microbes. The high bacterial diversity in diseased coral may be due to a

455 shift in the bacterial community structure from the equilibrium state. Reduction in

456 the immunity of the host may lead to colonization of opportunistic pathogens and 
457 directly or indirectly cause variations in normal microbiota. In addition, several

458 factors, such as disease lesions, symbiont composition, and micro-environmental

459 differences, provide new niches for the growth of specific bacteria, and therefore

460 increase the diversity of coral microbiota (Closek et al. 2014).

461 Coral physiological states and environmental factors, such as geography, water

462 quality, light exposure and season, have been reported to be important in terms of

463 their effect on the coral-associated bacterial community (Bourne et al. 2008; Koren

464 and Rosenberg 2008; Littman et al. 2009; Hong et al. 2009). In the current study,

465 we examined the influences of two factors, season and health status, on the

466 coral-associated consortia. Clone library data showed that Alphaproteobacteria

467 were dominant in summer, while Gammaproteobacteria and Alphaproteobacteria

468 were dominant in winter in both healthy and diseased corals, which indicate that the

469 seasonal factor may be more important in shaping the coral-associated bacterial

470 community.

471 BLAST searches of the ribotype clone-SD-14 in GenBank revealed that it

472 was homologous with clone 2D804 (JF411489, 100\% identity), an uncultured

473 member of the Alphaproteobacteria family that was previously identified in

474 skeletal tissue growth anomalies by other researchers (Chiu et al. 2012). Similar, 
475 but not identical, clones have been found in BBD (EF123405 and DQ441657)

476 (Sekar et al. 2006), white plague-like disease (FJ203320) (Sunagawa et al. 2009),

477 and Porites white patch syndrome (KF179790) (Sere et al. 2013) coral tissues.

478 This ribotype was also found to correspond with DGGE clone B21 and ribotype

479 clone-SD-7 (Fig. 5), which were present in the bacterial communities associated

480 with the WD and SD samples, respectively. This closely-related group of bacteria,

481 which is consistent in terms of appearance in diseased corals and absence in

482 healthy corals, represents potentially important PSS pathogens, and clearly

483 warrants further study.

484 We observed that Silicibacter was present in high abundance only in the

485 summer coral samples (35.62\% in $\mathrm{SH}$ and $22.73 \%$ in SD), revealing a shift in

486 bacterial flora in response to changing environmental conditions. To our

487 knowledge, this was the first study to report an abundance of sequences relating to

488 Silicibacter associated with coral in the summer months. A high abundance of

489 Silicibacter clones (greater than 20\%) was previously identified in bacterial

490 communities from corals collected in Monterey, California, suggesting the

491 possibility of dominance of Silicibacter in marine environments. Clones of this

492 group were found to be related to microbiota in healthy corals Acropora palmate 
493 (6.2\%) and Porites astreoides (2.0\%) in the Mexican Caribbean (McKew et al.

494 2012), as well as diseased coral Montipora aequituberculata of the Great Barrier

495 Reef (Jones et al. 2004b) and Siderastrea siderea of the Bahamas (Sekar et al.

496 2006).

497 Deltaproteobacteria, which contain ribotypes related to species of 498 sulfate-reducing bacteria (genius Desulfarculus), were detected in the $\mathrm{SH}$ 499 (2.74\%), SD (3.03\%) and WD (9.86\%) samples according to clone library data 500 (Fig. 4) and DGGE (Table S1) analysis. Sulfate-reducing bacteria have been 501 proposed as a causative agent for BBD (Sekar et al. 2006); however, it is 502 interesting to note that sulfate-reducing bacteria are also present in healthy corals 503 (Arboleda and Reichardt 2009), suggesting that they are likely to colonize 504 anaerobic niches in coral.

505 Four actinobacterial clones (B12, clone-SH-10, clone-SD-6 and clone-SD-13)

506 were identified in summer samples of both healthy and diseased coral.

507 Interestingly, BLAST analysis suggested that they are most closely matched to

508 sequences of bacteria associated with the marine sponge. Recently, several studies

509 (Lombo et al. 2006; Lampert et al. 2008; Chen et al. 2012) have shown that corals

510 harbor diverse species of Actinobacteria, some of which can produce antimicrobial 
511 substances. It has been suggested that resident microbial populations compete with

512 invading microbes for nutrients and ecological niches, and might play a major role

513 in coral health (Lampert et al. 2008). Coral has been suggested as an untapped

514 source of microbial diversity of economic importance (Chen et al. 2012). Further

515 studies are needed to confirm the possible production of antimicrobial substances

516 from marine bacteria isolated from Porites $\mathrm{sp}$.

517 In conclusion, we characterized the bacterial communities associated with

518 healthy and diseased Porites sp. coral with pink spot syndrome collected off the

519 coast of southern Taiwan.

520 Our results showed that primer set GC357F-518 was most suitable for

521 PCR-DGGE analysis of bacteria associated with healthy and diseased Porites sp.

522 coral collected off the coast of southern Taiwan. The bacterial communities of

523 Porites $\mathrm{sp}$. were found to be complex, and changed greatly between seasons and in

524 coral of differing health status. The diversity of the bacterial communities

525 associated with the coral increased in coral of a diseased state, as well as in coral

526 collected in the summer. In addition, our findings indicated that the season plays a

527 more important role in shaping the coral-associated bacterial community than

528 health status. Further investigation of interactions between the bacterial 
529 community and coral host under differing environmental conditions will provide

530 more information to enable elucidation of the roles of bacteria in coral diseases.

531

532 Acknowledgement

533 This work was supported by intramural funding from the National Museum

534 of Marine Biology and Aquarium.

535 


\section{References}

537 Aeby, G.S. 2003. Corals in the genus Porites are susceptible to infection by a $538 \quad$ larval trematode. Coral Reefs 22(3): 216.

539 Altschul, S.F., Gish, W., Miller, W., Myers, E.W., and Lipman, D.J. 1990. Basic

540 local alignment search tool. J. Mol. Biol. 215(3): 403-410.

541 Arboleda, M., and Reichardt, W. 2009. Epizoic communities of prokaryotes on 542 healthy and diseased scleractinian corals in Lingayen Gulf, Philippines. $543 \quad$ Microb. Ecol. 57(1): 117-128.

544 Bentis, C., Kaufman, L., and Golubic, S. 2000. Endolithic fungi in reef-building 545 corals (Order: Scleractinia) are common, cosmopolitan, and potentially 546 pathogenic. Biol. Bull. 198(2): 254-260.

547 Benzoni, F., Galli, P., and Pichon, M. 2010. Pink spots on Porites: not always a $548 \quad$ coral disease. Coral Reefs 29(1): 153.

549 Bourne, D., Iida, Y., Uthicke, S., and Smith-Keune, C. 2008. Changes in 550 coral-associated microbial communities during a bleaching event. ISME J.

551 2(4): $350-363$. 
552 Cardenas, A., Rodriguez, R.L., Pizarro, V., Cadavid, L.F., and Arevalo-Ferro, C.

553 2012. Shifts in bacterial communities of two Caribbean reef-building coral

$554 \quad$ species affected by white plague disease. ISME J. 6(3): 502-512.

555 Ceh, J., Van Keulen, M., and Bourne, D.G. 2011. Coral-associated bacterial 556 communities on Ningaloo Reef, Western Australia. FEMS Microbiol. Ecol.

$557 \quad$ 75(1): 134-144.

558 Chen, Y.-H., Kuo, J., Sung, P.-J., Chang, Y.-C., Lu, M.-C., Wong, T.-Y., Liu, 559 J.-K., Weng, C.-F., Twan, W.-H., and Kuo, F.-W. 2012. Isolation of marine 560 bacteria with antimicrobial activities from cultured and field-collected soft 561 corals. World J. Microbiol. Biotechnol. 28(12): 3269-3279.

562 Chimetto, L.A., Brocchi, M., Thompson, C.C., Martins, R.C., Ramos, H.R., and 563 Thompson, F.L. 2008. Vibrios dominate as culturable nitrogen-fixing bacteria 564 of the Brazilian coral Mussismilia hispida. Syst. Appl. Microbiol. 31(4): $565 \quad 312-319$.

566 Chiou, S.F., Kuo, J., Wongd, T.Y., Fan, T.Y., Tew, K.S., and Liu, J.K. 2010.

567 Analysis of the coral associated bacterial community structures in healthy and 568 diseased corals from off-shore of southern Taiwan. J. Environ. Sci. Health B 569 45(5): 408-415. 
570 Chiu, J.M., Li, S., Li, A., Po, B., Zhang, R., Shin, P.K., and Qiu, J.W. 2012.

571 Bacteria associated with skeletal tissue growth anomalies in the coral

572 Platygyra carnosus. FEMS Microbiol. Ecol. 79(2): 380-391.

573 Closek, C.J., Sunagawa, S., DeSalvo, M.K., Piceno, Y.M., DeSantis, T.Z., Brodie,

574 E.L., Weber, M.X., Voolstra, C.R., Andersen, G.L., and Medina, M. 2014.

575 Coral transcriptome and bacterial community profiles reveal distinct Yellow

576 Band Disease states in Orbicella faveolata. ISME J. 8(12): 2411-2422.

577 Cooney, R.P., Pantos, O., Tissier, M.D.A.L., Barer, M.R., O’Donnell, A.G., and

578 Bythell, J.C. 2002. Characterization of the bacterial consortium associated

579 with black band disease in coral using molecular microbiological techniques.

580 Environ. Microbiol. 4(7): 401-413.

581 Eichner, C.A., Erb, R.W., Timmis, K.N., and Wagner-Dobler, I. 1999. Thermal

582 gradient gel electrophoresis analysis of bioprotection from pollutant shocks in

583 the activated sludge microbial community. Appl. Environ. Microbiol. 65(1):

$584 \quad 102-109$.

585 Ferris, M.J., Muyzer, G., and Ward, D.M. 1996. Denaturing gradient gel

586 electrophoresis profiles of $16 \mathrm{~S}$ rRNA-defined populations inhabiting a hot

587 spring microbial mat community. Appl. Environ. Microbiol. 62(2): 340-346. 
588 Frias-Lopez, J., Bonheyo, G.T., and Fouke, B.W. 2004. Identification of

589 differential gene expression in bacteria associated with coral black band

590 disease by using RNA-arbitrarily primed PCR. Appl. Environ. Microbiol.

$591 \quad$ 70(6): $3687-3694$.

592 Frias-Lopez, J., Zerkle, A.L., Bonheyo, G.T., and Fouke, B.W. 2002. Partitioning

593 of bacterial communities between seawater and healthy, black band diseased,

594 and dead coral surfaces. Appl. Environ. Microbiol. 68(5): 2214-2228.

595 Hong, M.-J., Yu, Y.-T., Chen, C.A., Chiang, P.-W., and Tang, S.-L. 2009.

596 Influence of species specificity and other factors on bacteria associated with

597 the coral Stylophora pistillata in Taiwan. Appl. Environ. Microbiol. 75(24):

$598 \quad 7797-7806$.

599 Hsieh, Y. 2009. Inter-annual variation of lunar periodicity in larval release by reef

600 corals Pocillopora damicornis and Seriatopora hystrix. Master's Thesis,

601 National Dong Hwa University, Checheng, Pingtung, Taiwan.

602 Jones, G.P., McCormick, M.I., Srinivasan, M., and Eagle, J.V. 2004a. Coral

603 decline threatens fish biodiversity in marine reserves. Proc. Natl. Acad. Sci.

$604 \quad$ U.S.A. 101(21): 8251-8253. 
605 Jones, R.J., Bowyer, J., Hoegh-Guldberg, O., and Blackall, L.L. 2004b. Dynamics

606 of a temperature-related coral disease outbreak. Mar. Ecol. Prog. Ser. 281:

$607 \quad 63-77$.

608 Kellogg, C.A. 2004. Tropical archaea: diversity associated with the surface 609 microlayer of corals. Mar. Ecol. Prog. Ser. 273: 81-88.

610 Kimes, N.E., Johnson, W.R., Torralba, M., Nelson, K.E., Weil, E., and Morris,

611 P.J. 2013. The Montastraea faveolata microbiome: ecological and temporal

612 influences on a Caribbean reef-building coral in decline. Environ. Microbiol.

613 15(7): 2082-2094.

614 Koren, O., and Rosenberg, E. 2008. Bacteria associated with the bleached and

615 cave coral Oculina patagonica. Microb. Ecol. 55(3): 523-529.

616 Lampert, Y., Kelman, D., Nitzan, Y., Dubinsky, Z., Behar, A., and Hill, R.T.

617 2008. Phylogenetic diversity of bacteria associated with the mucus of Red Sea

618 corals. FEMS Microbiol. Ecol. 64(2): 187-198.

619 Lema, K.A., Willis, B.L., and Bourne, D.G. 2014. Amplicon pyrosequencing

620 reveals spatial and temporal consistency in diazotroph assemblages of the

621 Acropora millepora microbiome. Environ. Microbiol. 16(10): 3345-3359. 
622 Littman, R.A., Willis, B.L., Pfeffer, C., and Bourne, D.G. 2009. Diversities of

623 coral-associated bacteria differ with location, but not species, for three

624 acroporid corals on the Great Barrier Reef. FEMS Microbiol. Ecol. 68(2):

$625 \quad 152-163$.

626 Liu, Z., DeSantis, T.Z., Andersen, G.L., and Knight, R. 2008. Accurate taxonomy

627 assignments from 16S rRNA sequences produced by highly parallel

628 pyrosequencers. Nucleic Acids Res. 36(18): e120.

629 Lombo, F., Velasco, A., Castro, A., de la Calle, F., Brana, A.F., Sanchez-Puelles,

630 J.M., Mendez, C., and Salas, J.A. 2006. Deciphering the biosynthesis pathway

631 of the antitumor thiocoraline from a marine actinomycete and its expression in

632 two Streptomyces species. Chembiochem 7: 366-376.

633 Loya, Y., Sakai, K., Yamazato, K., Nakano, Y., Sambali, H., and van Woesik, R.

634 2001. Coral bleaching: the winners and the losers. Ecol. Lett. 4(2): 122-131.

635 Ludwig, W., Strunk, O., Westram, R., Richter, L., Meier, H., Yadhukumar,

636 Buchner, A., Lai, T., Steppi, S., Jobb, G., Forster, W., Brettske, I., Gerber, S.,

637 Ginhart, A.W., Gross, O., Grumann, S., Hermann, S., Jost, R., Konig, A.,

638 Liss, T., Lussmann, R., May, M., Nonhoff, B., Reichel, B., Strehlow, R.,

639 Stamatakis, A., Stuckmann, N., Vilbig, A., Lenke, M., Ludwig, T., Bode, A., 
640 and Schleifer, K.H. 2004. ARB: a software environment for sequence data.

$641 \quad$ Nucleic Acids Res. 32(4): 1363-1371.

642 McKew, B.A., Dumbrell, A.J., Daud, S.D., Hepburn, L., Thorpe, E., Mogensen,

643 L., and Whitby, C. 2012. Characterization of geographically distinct bacterial

644 communities associated with coral mucus produced by Acropora spp. and

$645 \quad$ Porites spp. Appl. Environ. Microbiol. 78(15): 5229-5237.

646 Muyzer, G., and de Waal, E.C. 1994. Determination of the genetic diversity of

647 microbial communities using DGGE analysis of PCR-amplified 16S rDNA. In

648 Microbial Mats: Structure, Development and Environmental Significance.

649 Edited by L.J. Stal and P. Caumette. Springer-Verlag, Heidelberg, Germony.

$650 \quad$ pp 207-214.

651 Muyzer, G., de Waal, E.C., and Uitterlinden, A.G. 1993. Profiling of complex

652 microbial populations by denaturing gradient gel electrophoresis analysis of

653 polymerase chain reaction-amplified genes coding for $16 \mathrm{~S}$ rRNA. Appl.

654 Environ. Microbiol. 59(3): 695-700.

655 Muyzer, G., Hottentrager, S., Teske, A., and Waver, C. 1996. Denaturing gradient

656 gel electrophoresis of PCR-amplified 16S rDNA. A new molecular approach

657 to analyze the genetic diversity of mixed microbial communities. In Molecular 
658 Microbial Ecology Manual. Edited by A.D.L. Akkermans, J.D. van Elsas and

659 F.J. de Bruijn. Kluwer Academic Publishing, Dordrecht, Nederland. pp

$660 \quad 3.4 .4 \cdot 1-3.4 \cdot 4.22$.

661 Muyzer, G., and Smalla, K. 1998. Application of denaturing gradient gel 662 electrophoresis (DGGE) and temperature gradient gel electrophoresis (TGGE) 663 in microbial ecology. Antonie van Leeuwenhoek 73(1): 127-141.

664 Ng, J.C., Chan, Y., Tun, H.M., Leung, F.C., Shin, P.K., and Chiu, J.M. 2015.

665 Pyrosequencing of the bacteria associated with Platygyra carnosus corals with 666 skeletal growth anomalies reveals differences in bacterial community 667 composition in apparently healthy and diseased tissues. Front Microbiol 6: $668 \quad 1142$.

669 Pantos, O., and Bythell, J.C. 2006. Bacterial community structure associated with 670 white band disease in the elkhorn coral Acropora palmata determined using 671 culture-independent 16S rRNA techniques. Dis. Aquat. Org. 69(1): 79-88.

672 Pruesse, E., Quast, C., Knittel, K., Fuchs, B.M., Ludwig, W., Peplies, J., and 673 Glockner, F.O. 2007. SILVA: a comprehensive online resource for quality 674 checked and aligned ribosomal RNA sequence data compatible with ARB. 675 Nucleic Acids Res. 35(21): 7188-7196. 
676 Ritchie, K.B., and Smith, G.W. 1995. Preferential carbon utilization by surface

677 bacterial communities from water mass, normal and white-band diseased 678 Acropora cervicornis. Mol. Mar. Biol. Biotechnol. 4(4): 345-352.

679 Roder, C., Arif, C., Daniels, C., Weil, E., and Voolstra, C.R. 2014. Bacterial 680 profiling of White Plague Disease across corals and oceans indicates a 681 conserved and distinct disease microbiome. Mol. Ecol. 23(4): 965-974.

682 Rohwer, F., Breitbart, M., Jara, J., Azam, F., and Knowlton, N. 2001. Diversity of 683 bacteria associated with the Caribbean coral Montastraea franksi. Coral Reefs $684 \quad 20(1): 85-91$.

685 Rohwer, F., Seguritan, V., Azam, F., and Knowlton, N. 2002. Diversity and 686 distribution of coral-associated bacteria. Mar. Ecol. Prog. Ser. 243: 1-10.

687 Rosenberg, E., Koren, O., Reshef, L., Efrony, R., and Zilber-Rosenberg, I. 2007. 688 The role of microorganisms in coral health, disease and evolution. Nat. Rev. $689 \quad$ Microbiol. 5(5): 355-362.

690 Sanchez, O., Gasol, J.M., Massana, R., Mas, J., and Pedros-Alio, C. 2007. 691 Comparison of different denaturing gradient gel electrophoresis primer sets 692 for the study of marine bacterioplankton communities. Appl. Environ. 693 Microbiol. 73(18): 5962-5967. 
694 Sekar, R., Kaczmarsky, L., and Richardson, L.L. 2008. Microbial community

695 composition of black band disease on the coral host Siderastrea siderea from

696 three regions of the wider Caribbean. Mar. Ecol. Prog. Ser. 362: 85-98.

697 Sekar, R., Mills, D.K., Remily, E.R., Voss, J.D., and Richardson, L.L. 2006.

698 Microbial communities in the surface mucopolysaccharide layer and the black

699 band microbial mat of black band-diseased Siderastrea siderea. Appl.

$700 \quad$ Environ. Microbiol. 72(9): 5963-5973.

701 Sere, M.G., Tortosa, P., Chabanet, P., Turquet, J., Quod, J.P., and Schleyer, M.H.

702 2013. Bacterial communities associated with Porites white patch syndrome

703 (PWPS) on three western Indian Ocean (WIO) coral reefs. PLoS ONE 8(12):

$704 \quad$ e83746.

705 Sunagawa, S., DeSantis, T.Z., Piceno, Y.M., Brodie, E.L., DeSalvo, M.K.,

706 Voolstra, C.R., Weil, E., Andersen, G.L., and Medina, M. 2009. Bacterial

707 diversity and White Plague Disease-associated community changes in the

708 Caribbean coral Montastraea faveolata. ISME J. 3(5): 512-521.

709 Wang, Q., Garrity, G.M., Tiedje, J.M., and Cole, J.R. 2007. Naive Bayesian

710 classifier for rapid assignment of rRNA sequences into the new bacterial

711 taxonomy. Appl. Environ. Microbiol. 73(16): 5261-5267. 
712 Wegley, L., Edwards, R., Rodriguez-Brito, B., Liu, H., and Rohwer, F. 2007.

713 Metagenomic analysis of the microbial community associated with the coral

$714 \quad$ Porites astreoides. Environ. Microbiol. 9(11): 2707-2719.

715 Yu, Z., Garcia-Gonzalez, R., Schanbacher, F.L., and Morrison, M. 2008.

716 Evaluations of different hypervariable regions of archaeal 16S rRNA genes in

717 profiling of methanogens by archaea-specific PCR and denaturing gradient gel

718 electrophoresis. Appl. Environ. Microbiol. 74(3): 889-893.

719 Yu, Z., and Morrison, M. 2004. Comparisons of different hypervariable regions of

720 rrs genes for use in fingerprinting of microbial communities by

721 PCR-denaturing gradient gel electrophoresis. Appl. Environ. Microbiol. 70(8):

$722 \quad 4800-4806$.

723

724 
Table 1. PCR primers used to amplify specific $16 \mathrm{~S}$ rRNA sequences for DGGE analysis.

\begin{tabular}{|c|c|c|c|c|c|c|}
\hline \multicolumn{2}{|c|}{ Primer pairs } & Primer sequence & \multirow{2}{*}{$\begin{array}{c}\begin{array}{c}\text { Target } \\
\text { region }\end{array} \\
\mathrm{V} 1-\mathrm{V} 3\end{array}$} & \multirow{2}{*}{$\begin{array}{c}\text { Amplicon } \\
\text { size (bp) } \\
489\end{array}$} & \multirow{2}{*}{$\begin{array}{c}\begin{array}{c}\text { Annealing } \\
\text { conditions }\end{array} \\
67-57^{\circ} \mathrm{C},-1^{\circ} \mathrm{C} / \text { cycle }\end{array}$} & \multirow{2}{*}{$\begin{array}{c}\begin{array}{c}\text { DGGE } \\
\text { conditions }\end{array} \\
6 \%, 45-65 \%, 100 \mathrm{~V}, 14 \mathrm{~h}\end{array}$} \\
\hline $\mathrm{A}$ & $63 \mathrm{~F}^{*}$ & 5'-GCCTAACACATGCAAGTC-3' & & & & \\
\hline \multirow[t]{2}{*}{$\mathrm{B}$} & $357 \mathrm{~F}^{*}$ & 5'-CCTACGGGAGGCAGCAG-3' & V3-V5 & 586 & $66-55{ }^{\circ} \mathrm{C},-1{ }^{\circ} \mathrm{C} /$ cycle & $6 \%, 45-65 \%, 100 \mathrm{~V}, 14 \mathrm{~h}$ \\
\hline & 907R & 5'-CCGTCAATTCMTTTGAGTTT-3' & & & & \\
\hline $\mathrm{C}$ & $357 \mathrm{~F}^{*}$ & 5'-CCTACGGGAGGCAGCAG-3' & V3 & 194 & $65-55^{\circ} \mathrm{C},-1{ }^{\circ} \mathrm{C} /$ cycle & $8 \%, 45-65 \%, 100 \mathrm{~V}, 14 \mathrm{~h}$ \\
\hline \multirow[t]{2}{*}{$\mathrm{D}$} & $968 \mathrm{~F}^{*}$ & 5'-AACGCGAAGAACCTTAC-3' & V6-V8 & 434 & $63-53{ }^{\circ} \mathrm{C},-1{ }^{\circ} \mathrm{C} /$ cycle & $6 \%, 45-65 \%, 100 \mathrm{~V}, 14 \mathrm{~h}$ \\
\hline & $1401 \mathrm{R}$ & 5'-CGGTGTGTACAAGACCC-3' & & & & \\
\hline \multirow[t]{2}{*}{$\mathrm{E}$} & $1055 \mathrm{~F}$ & 5'-ATGGCTGTCGTCAGCT-3' & V8 & 352 & $65-55^{\circ} \mathrm{C},-1{ }^{\circ} \mathrm{C} /$ cycle & $8 \%, 45-65 \%, 100 \mathrm{~V}, 14 \mathrm{~h}$ \\
\hline & $1392 \mathrm{R}^{*}$ & 5'-ACGGGCGGTGTGTRC-3' & & & & \\
\hline
\end{tabular}

*Primer with a 40-bp GC clamp at the 5' or 3' end.

GC clamp: 5'-CGCCCGCCGCGCGCGGCGGGCGGGGCGGGGGCACGGGGGG-3' 
664

665

666

667

668

669

670

671

672

673

674

675

676

677

678

679

680

681

\section{Figure Captions}

Fig. 1 DGGE profiles obtained from bacterial community DNA extracted from coral Porites sp. using five different 16S rRNA-targeted primer sets: (A) GC63F-518R; (B) GC357F-907R; (C) GC357F-518R; (D) GC968F-1401R; (E) 1055F-1392RGC (SH1-3: healthy summer coral; SD1-3: diseased summer coral; WH1-3: healthy winter coral; WD1-3: diseased winter coral).

Fig. 2 Cluster of bacterial communities associated with coral Porites sp. obtained using 16S rRNA-DGGE profiles with five different primer sets: (A) GC63F-518R; (B) GC357F-907R; (C) GC357F-518R; (D) GC968F-1401R; (E) 1055F-1392RGC. Dendrograms were constructed using the unweighted pair group method with arithmetic mean (UPGMA) according to Dice's coefficient (SH1-3: healthy summer coral; SD1-3: diseased summer coral; WH1-3: healthy winter coral; WD1-3: diseased winter coral).

Fig. 3 Distributions of (A) number of bands and (B) Shannon diversity index derived from denaturing gradient gel electrophoresis profiles of the bacterial community associated with Porites sp. for each primer set (SH: healthy 
682

683

684

685

686

687

688

689

690

691

692

693

694

695

696

697

698

summer coral; SD: diseased summer coral; WH: healthy winter coral; WD:

diseased winter coral).

Fig. 4 Percentage of bacterial phylum/class in each sample group for 269 bacterial clones from the bacterial community associated with Porites sp. using clone library analysis. (A) Healthy summer coral; (B) diseased summer coral (C) healthy winter coral; (D) diseased winter coral.

Fig. 5 Phylogenetic tree of $16 \mathrm{~S}$ rRNA sequences obtained from clone libraries and DGGE bands of Porites sp. samples. The tree was constructed using the ARB program, based on neighbor-joining analysis of a distance matrix using the Jukes-Cantor model. Bootstrap values of greater than 50\% are shown at branch points. The 16S rRNA sequences of the Methanococcus genus were used as the outgroup. The scale bars represent 0.10 substitutions per nucleotide position. Ribotypes marked with arrows are bacterial sequences mentioned in the Results and Discussion sections. 


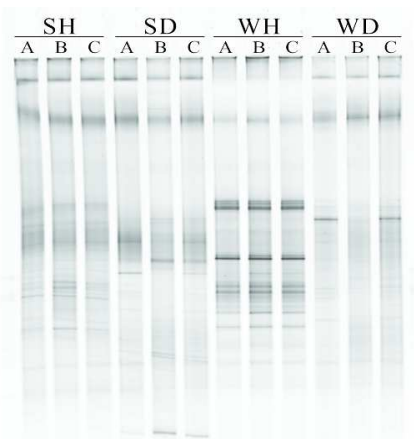

(A)

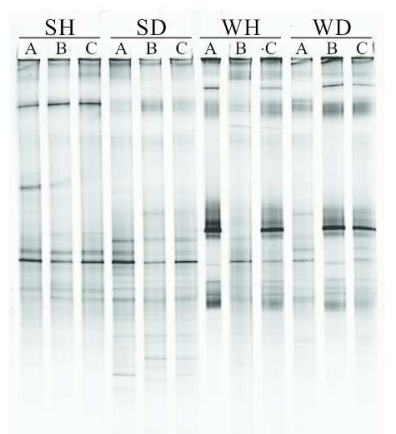

(B)
$\frac{S H}{A B C} \frac{S D}{A B C} \frac{W H}{A B C} \frac{W D}{A B C}$

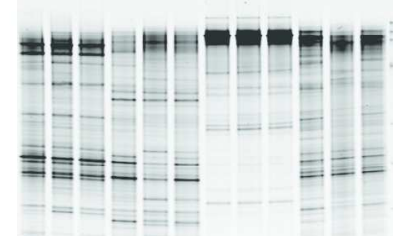

(C)

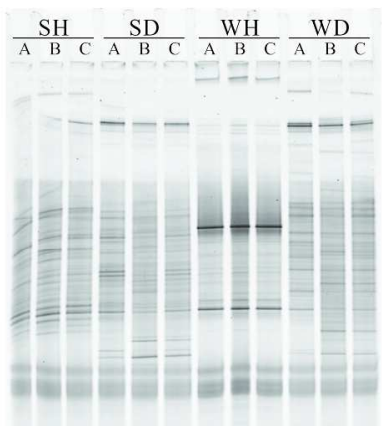

(D)

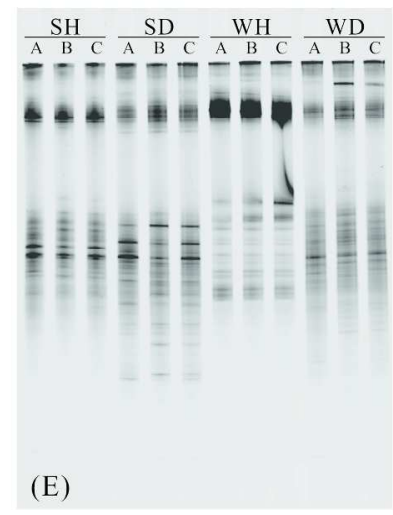

(E)

DGGE profiles obtained from bacterial community DNA extracted from coral Porites sp. using five different 16S rRNA-targeted primer sets: (A) GC63F-518R; (B) GC357F-907R; (C) GC357F-518R; (D) GC968F1401R; (E) 1055F-1392RGC (SH1-3: healthy summer coral; SD1-3: diseased summer coral; WH1-3: healthy winter coral; WD1-3: diseased winter coral).

$250 \times 200 \mathrm{~mm}(300 \times 300$ DPI $)$ 
Fig. 2.
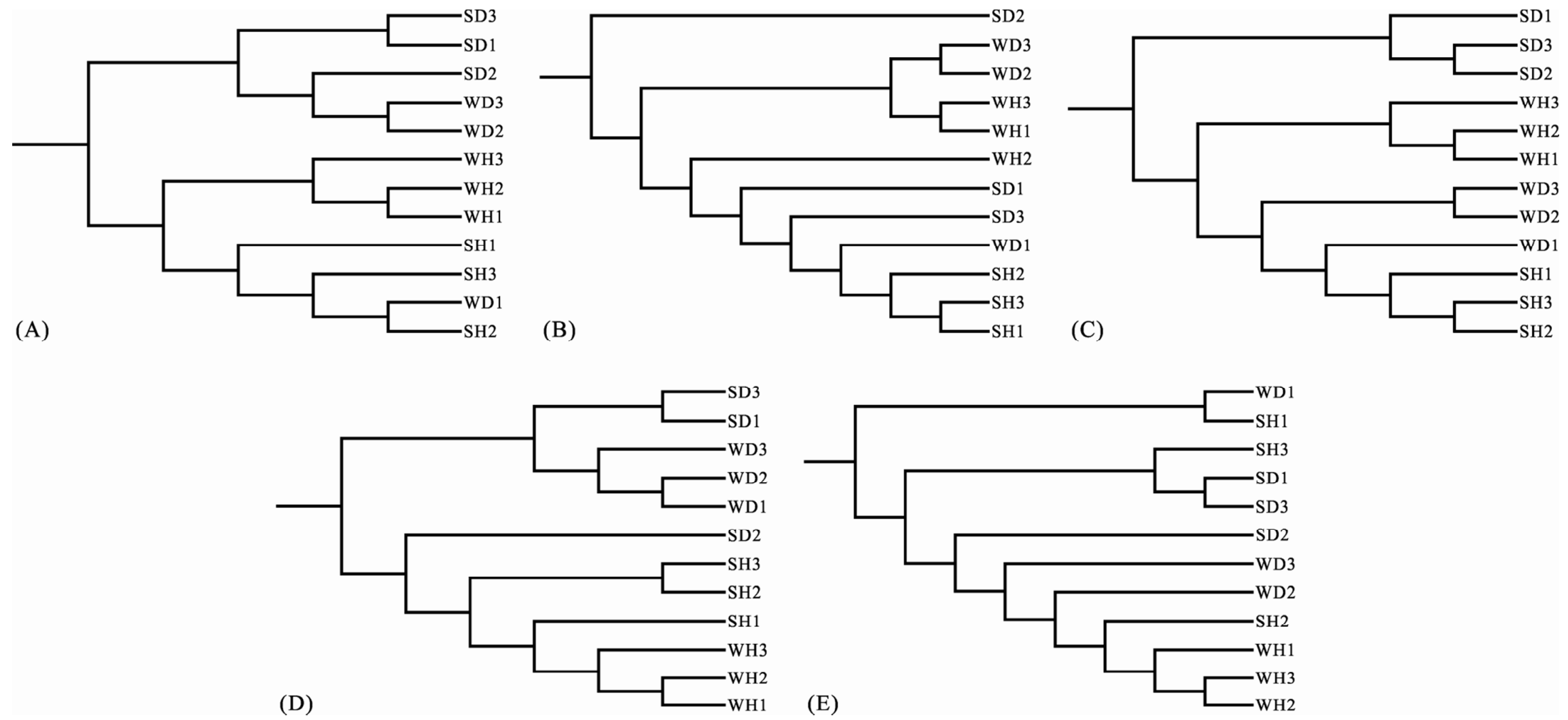
Fig. 3.
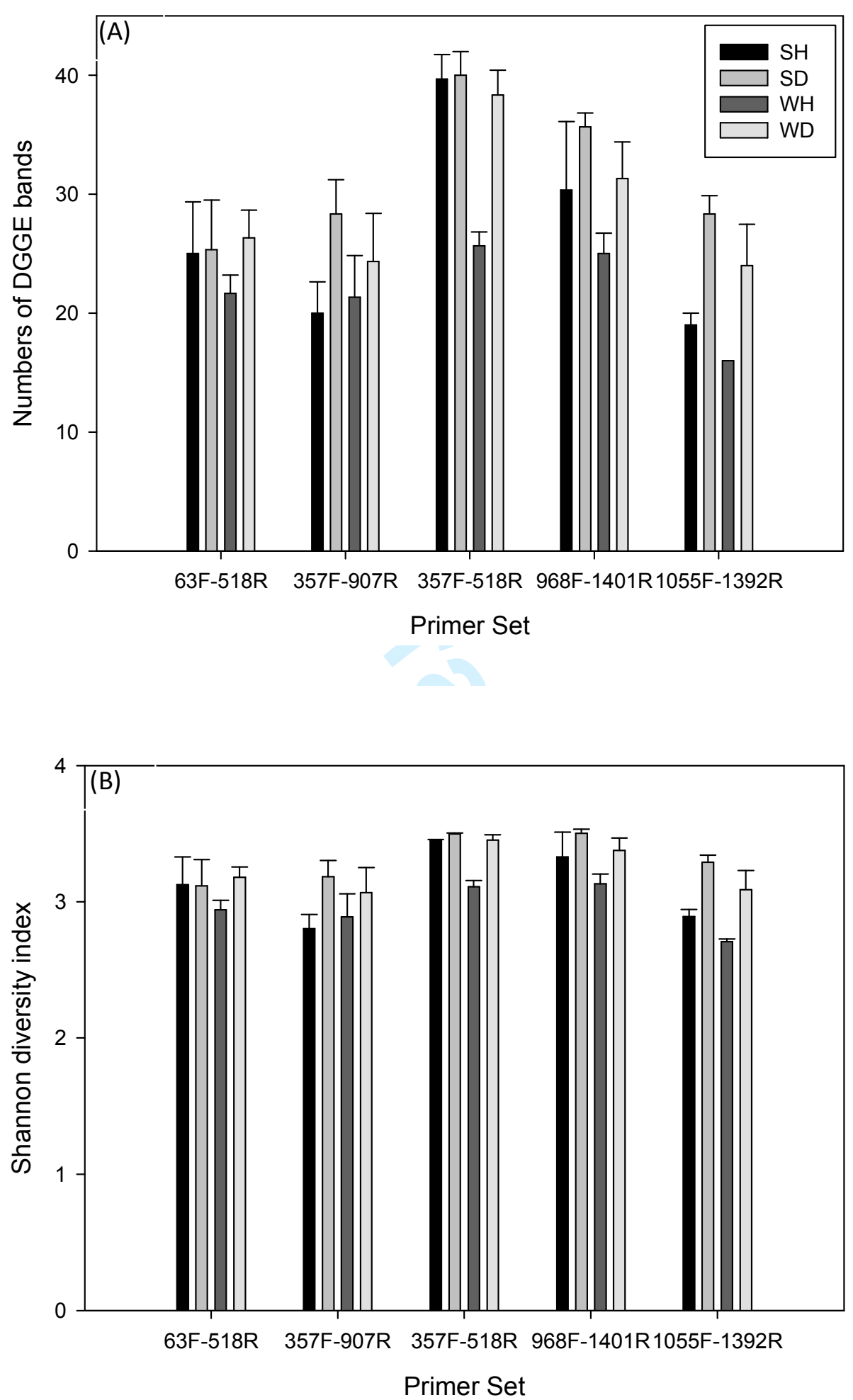
(A)

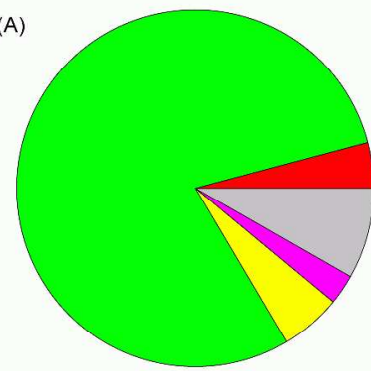

(C)

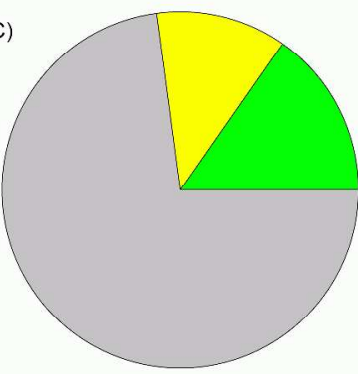

(B)

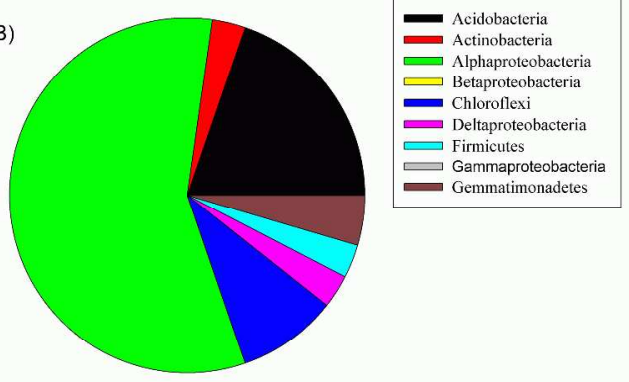

(D)

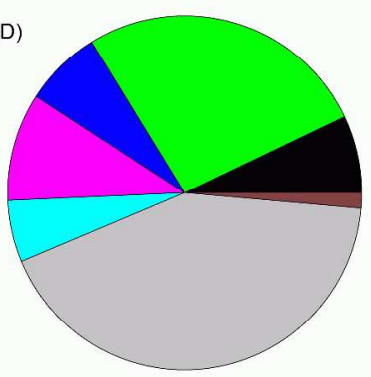

Percentage of bacterial phylum/class in each sample group for 269 bacterial clones from the bacterial community associated with Porites sp. using clone library analysis. (A) Healthy summer coral; (B) diseased summer coral (C) healthy winter coral; (D) diseased winter coral.

$2474 \times 1748 \mathrm{~mm}(72 \times 72 \mathrm{DPI})$ 
Fig. 5.

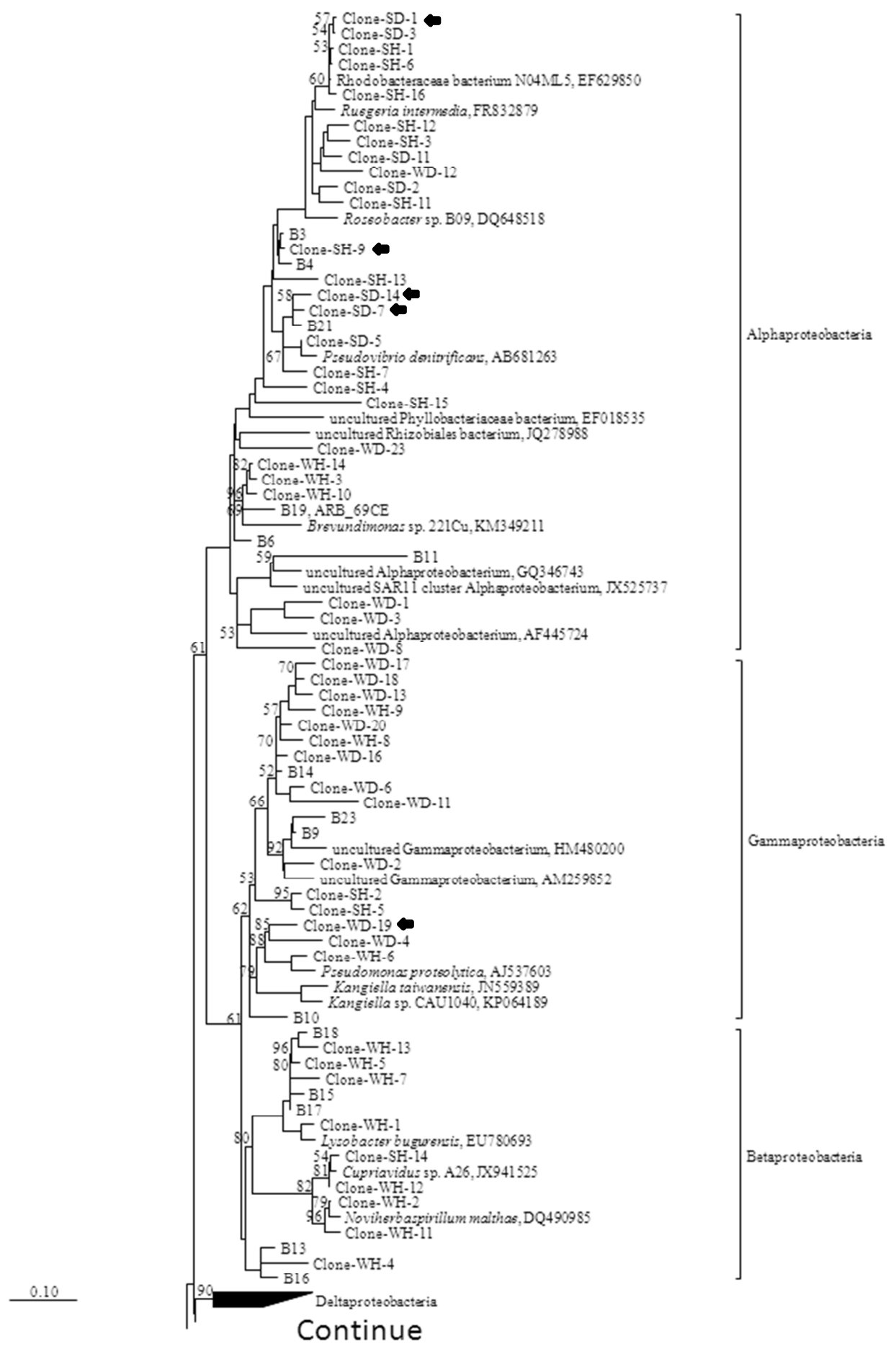




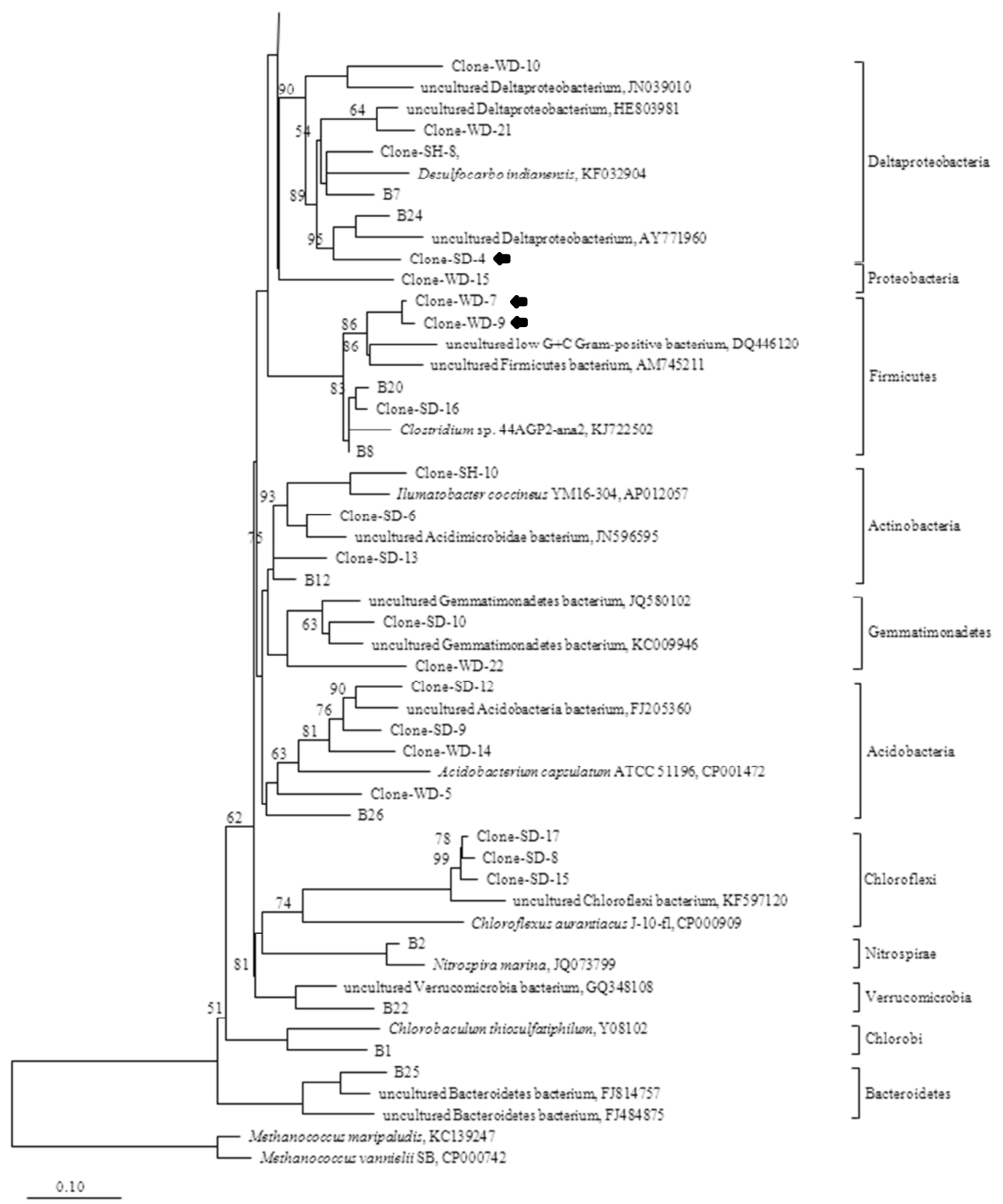

